\title{
Online Legal Research: A Practical Guide for Business Students
}

\section{and Professionals}

\author{
Jill M. Oeding $^{1 *}$, Shannon L. Hudson ${ }^{1} \&$ Jeanette C. Maier-Lytle $^{1}$ \\ ${ }^{1}$ Department of Accounting and Finance, University of Southern Indiana, Evansville, Indiana, USA \\ *Jill M. Oeding, E-mail: jmoeding@usi.edu
}

Received: May 9, 2017

Accepted: May 18, 2017

Online Published: May 25, 2017

doi:10.22158/jepf.v3n2p258

URL: http://dx.doi.org/10.22158/jepf.v3n2p258

\begin{abstract}
This article is intended to be a guide to business students and professionals in locating and assessing online legal information in the United States, providing a brief summary of primary and secondary sources of law and distinguishing between state and federal law as a backdrop to legal research. Researchers are encouraged to perform an online search with a tailored list of descriptive search terms. When evaluating online search results, a researcher should identify quality information based on its authority, accuracy, timeliness, objectivity, and coverage. If possible, online researchers should prefer government websites that provide timely, relevant information when retrieving online legal information. A researcher may begin an online search using secondary sources of law, but a successful search should conclude with the interpretation of primary sources of law.
\end{abstract}

\section{Keywords}

online legal research, internet, law

\section{Introduction}

This article was written as a guide for business students and professionals in performing online legal research, specifically with locating and assessing online information (Note 1). The ability to be a competent legal researcher would complement the skill set of any business position. Online legal research is a specialized discipline that requires an understanding of principles unique to the law.

Not all legal questions may be answered through an online search. Only a "small subset of legal materials are available on the internet", and primary sources of law, such as cases, statutes, and administrative regulations first became available on the internet in the mid-1990s (Murley, 2006). While online legal research is often fruitful in its returns, business students and professionals must realize that seeking legal counsel from an attorney often may be necessary. The researcher should consult an attorney when the researcher questions the reliability of the legal answer or when the legal issue has substantial ramifications. 


\section{Sources of Law}

When a researcher searches for an answer to a particular legal issue, the ability to distinguish between a primary and secondary source of law is essential. Primary sources of law establish the law in the United States (Cross \& Miller, 2015, p. 3), and these sources are "promulgated by government entities which designate an official source as the authoritative text of that primary law" (Guide to evaluating, 2016). Thus, primary sources include "the text of the law itself", while secondary sources generally provide an interpretation or overview of the law (Guide to evaluating, 2016). Therefore, a primary source of law that addresses the issue at hand is preferred over a secondary source. The four primary sources of American law are constitutions, statutes, common law, and regulations (Cross \& Miller, 2015, p. 3).

American law has two types of constitutions: state and federal. The federal constitution applies to all 50 states and U.S. territories. The U.S. Constitution is the highest law within the nation (Article VI, Clause 2). Each of the 50 states has its own constitution, and as long as a state's constitution does not conflict with the federal constitution, the state's constitution is the "supreme law" within that particular state (Cross \& Miller, 2015, p. 4).

The text of constitutions often requires interpretation through judicial decisions referred to as common law. Common law refers to rulings formulated by judges (i.e., courts) and is synonymous with the term "case law". Case law is the consequence of two or more parties who were involved in a legal dispute that resulted in litigation. Courts have the authority to shape law through the interpretation and application of existing law (Marbury v. Madison, 1803), thereby establishing common law as an important source of law.

The following example illustrates how common law shapes the law in the United States. For example, the Commerce Clause gives the U.S. Congress the power to "regulate commerce ... among the several states" (Article I, Section 8). In Wickard v. Filburn, the U.S. Supreme Court interpreted this language in a landmark case regarding a statute that limited the amount of wheat farmers could harvest (1942). The Supreme Court decided that Congress acted within the power of the Commerce Clause and upheld a ruling that Congress has the authority to regulate any activity that has a "substantial effect" on interstate commerce (Wickard v. Filburn, 1942, p. 129; Cross \& Miller, 2015, p. 122). The "substantial effect" language was not in the Constitution, yet the Supreme Court's interpretation of the meaning of the Commerce Clause set the precedent for many cases succeeding this 1942 ruling. This function of the courts to decide whether the legislative and executive branches acted within the scope of the Constitution is known as the power of judicial review (Marbury v. Madison, 1803; Cross \& Miller, 2015, p. 126). The Wickard case illustrates the power of the courts to shape the law through the use of common law rulings. Other critical concepts relevant to common law include precedent and stare decisis. Precedent is a "decision that furnishes an example of authority for deciding subsequent cases involving identical or similar legal principles or facts", and stare decisis is a doctrine that requires judges to follow precedent (Cross \& Miller, 2015, p. 8). Stare decisis makes the law more consistent and predictable. Researchers should seek cases that contain facts and legal principles similar to the issue they are researching. 
Furthermore, researchers should be aware that many legal cases are not available online or may be difficult to locate. If a legal issue is substantially governed by case law, the researcher should likely enlist an attorney's help.

Statutes are laws passed by legislatures at various levels of federal, state, and local government (Cross \& Miller, 2015, p. 3). The U.S. Congress enacts federal statutes, and state legislatures pass state statutes. Federal statutes are codified in the United States Code (USC). State statutes are codified in a source specific to each state. For example, Indiana statutes are codified in the Indiana Code; statutes passed by legislatures in Florida are referred to as Florida Statutes. Researchers should know the name of their particular state's codified laws; a state's code, such as Indiana Code, makes a valuable search term for online searching.

When reading statutes, researchers should not assume they know the meanings of terms within the statute. Terms are specifically defined within statutes, and the definition of a term within a statute may be different than a layman's definition of the term. An experienced researcher will review the definition section within a statute for a thorough understanding of the terms before proceeding with the statute interpretation.

Administrative laws, also known as regulations, are similar in form to statutes; however, administrative laws are created by administrative agencies. Administrative agencies are governmental boards with the power to make and enforce laws as prescribed by the state or federal legislatures (Cross \& Miller, 2015, p. 122). Administrative agencies may be state or federal bodies. Some examples of federal administrative agencies include the Securities and Exchange Commission, the Equal Employment Opportunity Commission, and the Occupational Safety and Health Administration. Some examples of state administrative agencies include Indiana's Bureau of Motor Vehicles, the Department of Workforce Development, and the Indiana Department of Education. Many administrative agencies have one of the following terms in the name of their agency: board, bureau, commission, agency, administration, or council. Researchers who retrieve a government website with one of these terms in the organization's name likely have located a reliable site.

Executive orders are another primary source of law worth noting because they frequently affect businesses. The president implements policies through executive orders in his capacity as the head of the executive branch (Chu \& Garvey, 2014). For example, President Obama issued an executive order raising the minimum wage to "\$10.10 for all workers on federal construction and service contracts" (Fact sheet: Final rule, 2014).

Secondary sources of law "explain or comment on primary law" and often provide references to primary sources of law (Guide to evaluating, 2016). Secondary sources may be created by private individuals or organizations. Examples of online secondary sources include scholarly journals, legal dictionaries, legal encyclopedias, and legal blogs (Guide to evaluating, 2016). Secondary sources generally provide an overview of legal principles and are often a worthy starting point for legal research (Kribble, 2016). A secondary source often educates the researcher on the general subject matter and discloses pertinent 
background information that can assist with understanding the legal issue. However, exclusive reliance on a secondary source to answer a legal question is not recommended. As the online search progresses, the researcher should seek primary sources of law, such as the text of a statute, case, regulation, or a constitution, where possible. In some cases, the secondary source may even lead the researcher to a primary source.

\section{State Law versus Federal Law}

When researching a particular legal issue, a researcher should discern whether the issue is controlled by state or federal law. When referring to the law, the term "federal" is generally synonymous with "United States". Federal law applies to all people and organizations in the United States (U.S.) and its territories, whereas state law applies only to those in the specific state in which the law was made (Commonly requested, n.d.). Federal laws are made by federal legislatures, judges, and administrative agencies pursuant to the U.S. Constitution, whereas state laws are made by state legislatures, judges and administrative agencies subject to the U.S. Constitution and each state's constitution.

The Supremacy Clause of the U.S. Constitution declares federal law, and specifically the U.S. Constitution, the highest law in the nation. The Supremacy Clause states that federal laws are the "supreme law of the land" (Article VI, Clause 2). The Supreme Court interpreted the Supremacy Clause to mean that when state and federal laws conflict with each other, state law is "without effect" (Maryland v. Louisiana, 1981), and, therefore, federal law prevails. In addition, the Supremacy Clause commissions the U.S. Constitution as the highest priority in the hierarchy of all laws; therefore, no state or federal laws may conflict with the U.S. Constitution.

The U.S. Constitution prescribes that the U.S. Congress has the power to legislate in certain areas, such as the imposition of taxes, interstate commerce, bankruptcy, and intellectual property (Article I, Section 8). The Tenth Amendment "reserves" legislative powers, other than those listed in Article I, Section 8, for state governments. On occasion, both federal and state legislatures pass laws on the same issue.

States are permitted to legislate the same issues as the federal government when the U.S. Congress specifies an intent in its statute to authorize state legislation (Medtronic, Inc. v. Lohr, 1996). State laws are generally permitted to grant more rights to people than the federal law. For example, the Fair Labor Standards Act (FLSA), a federal law, currently sets the hourly minimum wage amount at $\$ 7.25$ per hour for certain hourly employees working in the U.S. (Minimum wage, dol.gov, n.d.). Due to the FLSA, states are not permitted to set a minimum wage lower than $\$ 7.25$. However, the California legislature deemed an hourly wage of $\$ 7.25$ too low, so the legislatures raised the hourly minimum wage to $\$ 10.50$ per hour for employers with twenty-six or more employees and $\$ 10.00$ per hour for employers with twenty-five or less employees (Minimum wage, ca.gov, n.d.). Therefore, an entrepreneur opening a business in California would rely on the state minimum wage law, which requires employees to be paid at a higher rate than the federal law.

Federal law exclusively controls some legal issues. A researcher may determine that an issue, such as 
where to file a bankruptcy case, is controlled by federal law (Bankruptcy petition preparers, 2011). State legislatures are not permitted to legislate this issue because Congress had no intentions of enabling the states to determine which courts may handle bankruptcy cases. In other situations, federal law controls the issue because states refrained from enacting state laws on that particular issue. For example, the Indiana legislature chose not to pass a minimum wage law that is higher than the federal minimum amount of $\$ 7.25$ per hour and instead followed the federal law (Indiana minimum wage law, n.d.).

When an issue applies to a person or business in a particular state, that specific state's law should be researched, in addition to the federal law. A state-specific online search should be started by using a search term relevant to that state. For example, if an individual is searching for laws relevant to people and organizations located in Indiana, the researcher would locate more relevant sources by using "Indiana law" as a search term. If the online search results contain information on other states' laws, such as Ohio or Missouri, which are not pertinent to Indiana law, the researcher should continue seeking laws authorized by Indiana and federal lawmakers.

When researching a legal issue, a researcher should conduct a careful search of federal and state law to see which law controls the issue. Gaining familiarity with both primary and secondary sources of law will enable the researcher to discern which source is most relevant for their particular case. At the close of a legal search, the researcher must possess enough supporting documentation to potentially defend their position in a court of law.

\section{Search Terms}

A strong online search begins with a tailored list of descriptive search terms. Prior to tapping the first key of the keyboard, a researcher should take a few minutes to frame the legal issue. Then the researcher should compile a list of search terms by brainstorming various words that describe or pertain to the legal issue. The list should include synonyms for each significant term in the potential search because some search engines "are quite literal and do not deal well with words that have multiple meanings" (O'Hanlon, 2005). If only one version of a term is used in the search, a relevant source may not surface because the source contained something different than the search term. Terms within the content of the search results can also help the researcher fine-tune the list of search terms.

An internet search is generally narrowed by adding to the list of search terms, often returning more relevant search results. If the topic of this paper (i.e., online legal research) is used as an example and the single word "research" is typed in the Google search engine, the search engine returns millions of results that contain the word "research" (Note 2). However, if the researcher intends to locate results related to online, legal research, the researcher can narrow the results by including more search terms. The former example is narrowed to thousands of Google results by using the following search terms: online, internet, law, legal, evaluate, assess, information. This example can then be further refined by using search operators.

Search operators improve the researcher's likelihood of having a successful search. Examples of search 
operators include the use of quotation marks, a plus (+) or a minus sign (-), and words such as "site" (Refine web searches, n.d.) However, not all search engines use the same search operators. Researchers should become familiar with their preferred search engine's operators, which will expedite their research efforts.

For the sake of simplicity, the authors are going to concentrate on Google's search operators. If a researcher is searching for a particular phrase or words in a particular order, the researcher may enclose the entire phrase in quotation marks (e.g., "evaluating online sources"). If the researcher desires certain search terms to be included in the search results, a plus (+) sign may be placed right before the term (e.g., +online). Likewise, if the researcher wants to exclude results with a particular term, a minus sign may be placed before the term (e.g., -health). Finally, if a researcher wants to include all of the search words in each search result for the prior example, he or she could type the following in the search box: +online +legal +research +evaluate. This list of search terms reduces the Google search results to only 156 results (Note 3). Google also permits a researcher to search for sources from a particular website by using the word "site" followed by a colon. If the researcher prefers a certain type of website such as a government website, "site:gov" (without quotation marks) may be placed in the search field.

Another factor to consider when compiling a list of search terms is whether the legal question may be controlled by state or federal law. If the researcher is not clear which law is controlling, the researcher should conduct both a federal search and a state search. For example, if the researcher is researching hour restrictions for minors working in Florida, he or she should add "Florida law" and/or "Florida Statutes" to the list of search terms.

In order to become an efficient online researcher, one must learn to be proficient with search terms, search operators, and the specifics of search engines. In addition to being skilled in compiling a list of search terms, the researcher must be able to discern the value and relevancy of the search results.

\section{Discerning Online Sources for the Quality of Information}

If a student uses a search engine such as Google or Yahoo! to search for an answer to her legal question, the search results will return a list of resources including websites, images, and various files. The researcher should critically evaluate these results because any user can publish information on the web. Online information may be true, false, or simply an opinion. Unlike traditional, print sources that are professionally published, online information may not be subject to a "professional gatekeeper" (Metzger, 2007, p. 2078). "The internet has made the need to critically evaluate information more important than ever before while also shifting the burden of credibility assessment and quality control from professional gatekeepers onto individual information seekers" (Metzger, 2007, p. 2079). The researcher has an obligation to evaluate the search results and to identify quality information based on five criteria: (1) authority, (2) accuracy, (3) timeliness, (4) objectivity, and (5) coverage (Fritch \& Cromwell, 2001, p. 500; Metzger, 2007, p. 2079; Murley, 2006; see Knight \& Burn, 2005, p. 162). A thorough analysis of the sources against these five criteria will increase the likelihood of retrieving relevant and reliable 
information.

First, when assessing the results of an online search, students should determine the authority of the website; this criterion focuses on the author of the information. In the online environment, "nearly anyone can be an author, as authority is no longer a prerequisite for content provision on the Internet" (Metzger, 2007, p. 2078). The author of legal information may be a governmental body, a scholarly academic, a practicing professional, a legal organization, or a random person. A researcher should glance through the results list, paying special attention to the top-level domain name. A top-level domain name, or domain suffix, refers to the series of letters after the domain name in the web address (41 C.F.R. $\S 102-173.5)$. For example, in the United States Department of Labor's website, http://www.dol.gov, "dol" is the domain name, and the top-level domain name, or domain suffix, is "gov", which denotes a government web address. When researching a legal question, if possible, students should "go straight to the horse's mouth" by looking for an answer from the appropriate governmental authority that bests answers the legal question. Non-military government websites typically have domain names that end in “.gov" (Murley, n.d.).

A government website will generally provide reliable data. However, even government websites are not foolproof; data could be outdated or biased. For example, http://www.whitehouse.gov tends to be biased towards the current administration's viewpoints. As a result of this finding, government websites should be analyzed with the same scrutiny as other types of sites.

If a government website is unavailable, a decent second choice of websites would be an educational institution's web page, which would likely have a domain suffix of ".edu" (Murley, n.d.). If the legal answer cannot be determined using information from a current website ending in ".gov" or ".edu," the researcher must carefully evaluate alternative sites. Commercial enterprises typically have domain names that end in ".com" (Murley, n.d.). Researchers should be wary of ".com" sites as they may be biased, shedding a positive light on their product or service offerings. Non-profit organizations, commonly denoted with an ".org" domain suffix, may be a reliable source, depending on the organization and its motives.

In addition to checking a source's domain suffix, a researcher should review the author's credentials. If the author is an individual, credentials may include education, legal experience, or an affiliation with a legal organization. Authors who are organizations should be scrutinized for bias and credibility. If the author does not have sufficient legal credentials, the researcher should not rely on the information on the site. If a web page does not disclose the author, the information should not be trusted.

The second of the five criteria in assessing online information is accuracy. The accuracy of information may be verified by asking questions such as whether sources for the information are listed, whether the information appears to be fact or opinion, whether the sources could be substantiated by an independent source, and finally whether the web site is free from grammatical, spelling, or typographical errors (Fritch \& Cromwell, 2001). Fortunately, legal writers tend to provide citations for their sources. Documents such as court cases, scholarly legal articles, and legal websites often cite their sources. 
Researchers should review the citations within the legal sources because the sources often lead researchers to other sources, possibly even primary sources. Comparing sources can improve the overall accuracy of research information.

Suppose a business student or professional is searching for the necessary actions to file an employment discrimination claim. The student may first locate information in a secondary source consisting of an attorney's website who practices employment law. While the attorney may have excellent qualifications, a better source of the information would be a government website, such as the Department of Labor or the Equal Employment Opportunity Commission.

Timeliness of the online information is the third criteria researchers should assess. Researchers of the law should pursue the most up-to-date information possible because the law is ever-changing (Guide to evaluating legal, 2016). New statutes are passed by legislatures, and administrative agencies are constantly promulgating new regulations. In addition, courts are constantly issuing new decisions. Researchers should be aware that some websites are monitored more closely for real-time information than others. Consequently, researchers should search for a publication date or the most recent update. If a researcher finds a web page that has not been recently updated, the researcher should be leery of the information; the website may not be well maintained. Research that uncovers opposing information may be evidence of recent changes in the law.

The fourth assessment criterion is objectivity. The researcher should identify the site's purpose and assess the information for potential bias, which could ultimately affect the dependability of the information (Metzger, 2007). Reliable websites should focus more on how the law stands rather than opinion; the information should be factual and not based on emotions or personal prejudices.

The fifth criterion is coverage. Coverage speaks to the "comprehensiveness or the depth of the information" (Metzger, 2007, p. 2079). The researcher should question whether the source provides the entire picture or just one piece of the puzzle. Researchers should also check several reliable sites for consistency in their findings.

Since online information is often not subject to professional editing, a business researcher should evaluate sources for authority, accuracy, timeliness, objectivity, and coverage. Strong online researchers should give precedence to timely, objective information derived from government websites.

\section{Alternative Legal Websites}

Many legal websites exist beyond the government sources, but researchers should be cautious in blindly relying on them. As mentioned earlier, a legal researcher's first preference should be a government website. If a government site is not available, then Cornell Legal Information Institute, FindLaw, and Google Scholar are generally valuable online legal resources.

The Legal Information Institute (LII) is a nonprofit group affiliated with the Cornell University Law School that "believes everyone should be able to read and understand the laws that govern them, without cost" (Legal information institute, n.d.). LII's objective is to simplify the process of finding and 
understanding the law. Cornell's LII has an extensive collection of free legal resources, providing online legal researchers access to a wide assortment of primary resources, including federal and state court opinions, statutes, constitutions, and administrative law. Many of the links on LII's website direct researchers to the appropriate government website.

In addition to LII, Findlaw and Google Scholar are generally beneficial websites for online searches. FindLaw can assist business researchers in obtaining legal information. FindLaw, a business owned by Thomson Reuters, provides internet marketing solutions for law firms and online legal information for consumers and small businesses (About Findlaw, n.d.). FindLaw often educates the consumer as a secondary source of law, providing a general background on specific areas of the law. However, the business researcher should not solely rely on this type of website for a definitive answer. Google Scholar is a search engine that provides an easy way to search for scholarly literature, enabling researchers to search "articles, theses, books, abstracts and court opinions, from academic publishers, professional societies, online repositories, universities and other web sites" (About Google Scholar, n.d.).

While researchers should generally prefer information from government websites, the Legal Information Institute, Findlaw, and Google Scholar are also beneficial in conducting legal research. As with all sources, researchers should evaluate information from these sources for authority, accuracy, timeliness, objectivity, and coverage.

\section{An Example Applying Research Recommendations}

The proceeding example will demonstrate how to apply the concepts recommended in this paper (Note 4). The following hypothetical situation, typical of the legal questions that businesses face, will be used to show how an individual may perform online legal research:

John is a manager for Patriot Countertops ("Patriot"), a business with 75 full-time employees in Indianapolis, Indiana. Frank, an employee under John's supervision who has worked for Patriot for ten years, informs John that his grandmother is terminally ill with lung cancer. Frank is especially close to his grandmother because she raised him as a child. Frank would like to take time off work to take his grandmother to health care appointments and to provide general care for her. John is vaguely familiar with a law that allows some employees to take time off work to care for family members. John must perform online research to see how the law applies to Frank's situation.

A business student or professional with a legal issue similar to this scenario should first identify the potential legal issue(s) in the situation. The legal issue in this hypothesis is whether the business is legally required to permit John to take time off work to care for his grandmother.

Next, the student or professional should brainstorm a list of relevant search terms, including synonyms for significant words, keeping in mind that this issue could be controlled by state or federal law. Initial brainstorming might generate the following brief list of online search terms: leave, work, grandparent, and health condition. Since a government website is preferred in online legal research, the researcher should include "site:gov" or just ".gov" in his or her search terms. The search term "site:gov" denotes 
that the researcher wants to view only government websites. Brainstorming can be extremely valuable as the additional time brainstorming may generate several synonyms for the list of search terms. The authors generated the following list of terms that was used for the first Google search: site:gov, leave, time off work, parent, grandparent, medical condition, health condition, care.

The first couple of results generated from the search were sources from the Federal Office of Personnel Management (OPM). At first glance, the OPM search results appeared to be applicable to the legal issue at hand because the results contain information regarding the entitlement of employees to sick leave for care of a family member. However, the OPM is an example of how some government websites are not pertinent to the researcher's particular legal issue, even though they may at first appear applicable. An analysis of the accuracy and coverage of this website uncovered that the OPM was not on-point. The OPM is an administrative agency that performs human resource functions for employees of the federal government (Our agency, n.d.), and the information on the website was a human resource policy applicable to certain federal employees, not to private employees, as would be the case with the hypothetical example involving Patriot.

If the researcher continues to read through the search results, the researcher will notice a valuable result from the Wage and Hour Division of the U.S. Department of Labor (DOL), a federal administrative agency. The DOL webpage lists general eligibility information for employers and employees regarding the Family and Medical Leave Act of 1993 (FMLA) (FMLA frequently asked questions, n.d.). The source confirms that the FMLA applies to Patriot as an employer covered by the FMLA with more than 50 employees and to Frank as an eligible employee who meets the requisite employment criteria of the FMLA. The DOL webpage states that "a covered employer must grant an eligible employee up to a total of 12 workweeks of unpaid, job-protected leave in a 12 month period ... to care for a ... spouse, child, or parent ... with a serious health condition" (FMLA frequently asked questions, n.d.). Since Frank is requesting leave to care for his grandparent rather than parent, at first it may appear that John can legally deny Frank's request to take a leave of absence. However, further research must be conducted because the DOL source refers to a concept known as "in loco parentis", a person who stands in for a parent. Based on information obtained from the first search, another search should be performed to determine whether Frank's grandmother may qualify as a "parent" for Frank since he was raised by his grandmother. A new list of search terms should be generated given the new information retrieved from the first search. First, the title of the applicable federal law, the FMLA, should be listed in the second search in addition to whether a grandparent may qualify as a "parent" under the Act. The authors generated the following list of search terms for the second search: site:gov, Family and Medical Leave Act, definition of parent, grandparent, in loco parentis.

The first result of the parent/grandparent issue was a DOL Fact Sheet, which explained the definition of a "parent" as it applies to an individual standing "in loco parentis" to the employee (Fact sheet \#28C, 2015). The Fact Sheet cited primary, statutory authority for the definition of "parent" under the FMLA, leading the researcher directly to the text of the statute, a primary source of law. The FMLA statute defined a 
"parent" as the "biological parent of an employee or an individual who stood in loco parentis to an employee when the employee was a son or daughter" (29 U.S.C. § 2611(7)). When defining "in loco parentis", the regulations included "persons with day-to-day responsibilities to care for or financially support a child" (Fact sheet \#28C, 2015). The Fact Sheet stated:

An eligible employee is entitled to take FMLA leave to care for a person who provided such care to the employee when the employee was a child. If the individual stood in loco parentis to the employee when the employee was a child, the employee may be entitled to take FMLA leave even if he or she also has a biological, step, foster, or other parent, provided that the in loco parentis relationship existed between the employee and the individual when the employee met the FMLA's definition of a "son or daughter" (Fact sheet \#28C, 2015).

In providing the definition of an individual standing "in loco parentis" to the employee, the Fact Sheet specifies that the pertinent timing of the "in loco parentis" relationship was when the employee, the hypothetical Frank, was a "son" as defined by the FMLA, (Fact sheet \#28C, 2015), stimulating the need to research the definition of a "son or daughter" under the Act. The definition of a "son or daughter" was researched by using the following terms: Family and Medical Leave Act, definition of son or daughter, and United States Code. These search terms led the researcher to an official interpretation of the language in question, which in turn led the researcher to the statutory definition of a "son or daughter" in the FMLA in 29 U.S.C. $§ 2611$ (12) (Administrator's interpretation no. 2010-3, 2010). Based on an analysis of the primary and secondary sources of law, Frank satisfied the definition of a "son" under the FMLA since he was a "child of a person standing in loco parentis, who is under 18 years of age" (29 U.S.C. $\S$ 2611(12)).

Since the first set of searches involved federal law, a state law search must be performed to ensure the state laws do not differ from federal law. Since Frank is employed in Indiana, Indiana law is relevant. A state law search should include the search terms "Indiana law" or "Indiana Code" in addition to the initial list of search terms. Several Indiana-related searches through Google revealed that no Indiana law existed that was pertinent to Frank's employment issue. Therefore, the federal FMLA controlled this issue.

After reading the primary and secondary sources of law, specifically the statutes and agency interpretations pertaining to Frank's medical leave issue, a researcher could be fairly confident that, in the hypothetical, Frank may take a qualified leave under the FMLA to care for his grandmother, who stood in as his parent during his childhood. This conclusion was derived by analyzing primary and secondary sources of law derived from the Department of Labor, a federal administrative agency.

\section{Conclusion}

A business student or professional who approaches online legal research can employ some tactics to increase the likelihood of retrieving reliable, useful information. A researcher should identify the legal issue and develop focused search terms for the search engine. While combing through the search results, the researcher should primarily concentrate on primary sources of law and information related by Published by SCHOLINK INC. 
government sources. Primary law sources state the exact text of the law from constitutions, statutes, the common law, and administrative law as opposed to secondary law sources, which are second-hand interpretations of the primary source. A savvy researcher will analyze each source for its authority, accuracy, timeliness, objectivity, and coverage to discern its validity and usefulness regarding the legal issue.

The information in this paper is not meant to convert business students and professionals into lawyers. Rather, this paper is intended to introduce basic principles relevant to online legal research. Business students and professionals face many potentially challenging legal dilemmas that may be overcome by knowing how to perform online research. The more online legal research a person performs, the more skilled he or she will become in discerning which search terms to use and which sites are most reliable. Wise researchers must be able to discern when their research leads them to an accurate answer and when it is time to contact an attorney.

\section{References}

About Findlaw. (n.d.). Findlaw. Retrieved May 8, 2017, from http://www.company.findlaw.com/

About Google Scholar. (n.d.). Google Scholar. Retrieved May 8, 2017, from https://www.scholar.google.com/intl/en/scholar/about.html

Administrator's interpretation number 2010-2013. (2010, June 22). Department of Labor. Retrieved May 8, 2017, from https://www.dol.gov/whd/opinion/adminintrprtn/fmla/2010/fmlaai2010_3.htm

Bankruptcy petition preparers. (2011, July 13). United States Department of Justice. Retrieved May 8, 2017, from https://www.justice.gov/sites/default/files/ust-regions/legacy/2011/07/13/bank_pet_ prep.pdf

Chu, V., \& Garvey, T. (2014, April 16). Executive orders: Issuance, modification, and revocation. Retrieved May 8, 2017, from https://www.fas.org/sgp/crs/misc/RS20846.pdf

Commonly requested U.S. laws and regulations. (n.d.). Federal Laws and Regulations. USA.gov. Retrieved May 8, 2017, from https://www.usa.gov/laws-and-regulations

Constitution of the United States. (n.d.). National Archives. Retrieved May 8, 2017, from http://www.archives.gov/exhibits/charters/constitution_transcript.html

Cross, F., \& Miller, R. L. (2015). The legal environment of business (9th ed.). Stamford, CT: Cengage Learning.

Fact Sheet \#28C: The definition of "parent" as it applies to an individual who stood in loco parentis to an employee for FMLA “eldercare” protections. (2015, July). United States Department of Labor. Retrieved May 8, 2017, from https://www.dol.gov/whd/regs/compliance/whdfs28c.pdf

Fact sheet: Final rule to implement executive order 13658, establishing a minimum wage for contractors. (2014). United States Department of Labor. Retrieved May 8, 2017, from https://www.dol.gov/whd/flsa/eo13658/fr-factsheet.htm

Family and Medical Leave Act of 1993, 29 U.S.C. § 2611. (n.d.). 
FMLA frequently asked questions. (n.d.). United States Department of Labor. Retrieved May 8, 2017, from https://www.dol.gov/whd/fmla/fmla-faqs.htm

Fritch, J., \& Cromwell, R. (2001). Evaluating internet resources: Identity, affiliation, and cognitive authority in a networked world. Journal of the American Society for Information Science and Technology, 52(6), 499-507.

Guide to evaluating legal information online. (2016, July). American Association of Law Libraries. Retrieved May 8, 2017, from http://www.aallnet.org/mm/Advocacy/access/ evaluatelegalinfoguide.html

Indiana minimum wage law. (n.d.). Indiana Department of Labor. Retrieved May 8, 2017, from http://www.in.gov/dol/files/Indiana2009MinimumWage.pdf

Knight, S., \& Burn, J. (2005). Developing a framework for assessing information quality on the world wide web. Informing Science Journal, 8, 159-172.

Kribble, M. (2016, June 9). Secondary sources: ALRs, encyclopedias, law reviews, restatements, \& treatises. Harvard Law School Library. Retrieved May 8, 2017, from http://www.guides.library.harvard.edu/secondary

Legal Information Institute. (n.d.). Cornell University Law School. Retrieved May 8, 2017, from https://www.law.cornell.edu/

Marbury v. Madison, 5 U.S. 137. (1803).

Maryland v. Louisiana, 451 U.S. 725. (1981).

Medtronic, Inc. v. Lohr, 518 U. S. 470. (1996).

Metzger, M. (2007). Making sense of credibility on the web: Models for evaluating online information and recommendations for future research. Journal of the American Society for Information Science and Technology, 58(13), 2078-2091.

Minimum wage. (n.d.). State of California Department of Industrial Relations. Retrieved May 8, 2017, from http://www.dir.ca.gov/dlse/faq_minimumwage.htm

Minimum wage. (n.d.). United States Department of Labor. Retrieved May 8, 2017, from https://www.dol.gov/whd/minimumwage.htm

Murley, D. (2006). Evaluating and rating websites and other information resources. Southern Illinois University School of Law Library. Retrieved May 8, 2017, from http://www.law.siu.edu/lawlib/guides/eval.htm

Murley, D. (n.d.). Introduction to the internet: Addresses and domain names. Retrieved May 8, 2017, from http://www.law.siu.edu/lawlib/guides/internetintro.htm

O'Hanlon, N. (2005, May 23). The right stuff: Research strategies for the internet age. Ohio State $\begin{array}{lllll}\text { University } & \text { Libraries. } & \text { Retrieved } & \text { May }\end{array}$ https://www.liblearn.osu.edu/tutor/rightstuff.html

Our Agency. (n.d.). Office of Personnel Management. Retrieved May 8, 2017, from https://www.opm.gov/about-us/ 
Refine web searches. (n.d.). Google. Retrieved May 8, 2017, from https://www.support.google.com/websearch/answer/2466433?hl=en

What is Internet GOV Domain? 41 C.F.R. §102-173.5. (n.d.)

Wickard v. Filburn, 317 U.S. 111. (1942).

\section{Notes}

Note 1. These research guidelines were designed to supplement a business law course, equipping business students with basic legal research skills that may be helpful in their future positions. This paper does not constitute legal advice, should not be interpreted as legal advice, and is presented without any representation or warranty as to its accuracy, completeness, or timeliness. The issues herein contained are used as examples for teaching purposes only.

Note 2. The authors are not in any way affiliated with Google. The authors use Google as an example because of their familiarity with this particular search engine.

Note 3. Google also offers an "Advance Search" option that permits the researcher to tailor a search.

Note 4. This hypothetical legal issue was researched on May 9, 2017. The results in this paper are consistent with the results obtained from a Google search on this particular date. 